\title{
European Community Responses to the 'Problem of World Hunger'. Food Aid, Food Security, Food Strategies and All That
}

\author{
Edward Clay
}

\section{The Community Context}

The 'problem' of world hunger has recently received considerable attention within the European Community in reports and debates of the European Parliament [1980,1982]. The EC Commission [1981, 1982] and the Council of Ministers (1981) have in turn responded in a policy context. The subject is so vast that inevitably there is a need to identify priority areas for discussion. One such area of concern is potential European response to the acute short term problems of economic adjustment being faced by low income countries. Mr Pisani has also accorded priority to providing food security in the context of effective strategies for rural development [EC Commision 1982]. There are considerable overlaps between these areas of concern, and recent experiences and policy analysis have tended to underscore the significant policy implications of recognising linkages between the discussions. A necessary starting point for policy discussion is a clearer understanding of the complexities of the problems of hunger and poverty to which national and international policies are addressed.

\section{Characteristics of the 'Hunger Problem'}

What are the problems of hunger and poverty? There is not so much a single problem of world hunger as related sets of problems which have different implications for policy at national and international levels. Different elements of EC trade and aid policies have an impact on particular aspects of these problems. The complexity of these questions is indicated if one focuses only on the problem of food insecurity - risks to the target levels of food consumption of households, communities and nations. It is important to distinguish between the different problems of food insecurity and their quite different policy implications. This is not always easy, since interventions to combat these problems are necessarily institutionalised in different policy contexts [Clay and others 1981; Clay 1982]. Broadly, three categories of food insecurity problems can be recognised: short term emergencies; short term regional or national food insecurity; and international food insecurity resulting from instability of world food markets.
Short term emergencies These occur where groups or regions are confronted with short term threats to food consumption. They raise a range of policy problems depending on the circumstances, scale, and expected duration of the threat. This article does not give at tention to emergencies, but it should be noticed in passing that the complexities of the problem are compounded by the many international parties involved. From the viewpoint of the major development assist ance agencies, there is an inherent dilemma involved in the recognition of, and response to, emergencies. There are powerful political pressures to become involved. But all too often, the nature of the emergency and the lags in information, as well as the decision processes of agencies, preclude significant responses before the initial emergency phase has passed. ${ }^{1}$

Short term regional or national food insecurity The macro aspect of such problems, reflected in pressure on aggregate food consumption, has made this a primary area of concern in national and international discussions of food security. The actual problems of food insecurity are, however, characteristically sectoral and regional, affecting particular groups within societies. A profile of the longer term problems of poverty, malnutrition and hunger which involve periodic and seasonal pressures on food consumption will indicate the vulnerable groups. Food insecurity is likely to have distinctive rural and urban as well as regional dimensions. Women and small children are more likely to be severely affected. Particular occupational groups such as agricultural labour and plantation workers are often more vulnerable. As attention shifts to these longer term problems and to the groups who are most vulnerable, a link is underscored between food security, poverty and agricultural and rural development. Recognition of this linkage has fostered an interest in articulating policies which simultaneously respond to short term problems of food insecurity and longer term problems of agricultural development at the individual country level. These are the so-called 'food strategies' discussed below.

'See Clay and Pryer [1982:7-12], Table 2, for a typology of emergencies and the institutional responses involved in these problems. 
International food insecurity The food crisis of the early 1970s underscored the vulnerability of low income countries to short term fluctuations in world cereal markets. The rapid increase in costs of food imports coinciding with the rapid increase in energy prices created severe short run adjustment problems for many low income countries. These events focused attention on world grain markets in which the EC has come to be a significant force both as an exporting and as an importing trade group. However, as subsequent events have demonstrated, it is misleading to focus solely on fluctuations in cereal markets as the source of food insecurity created by short run adjustment problems. More important is the fact that many more developing countries have become vulnerable to movements in the world economy because of structural changes in their agricultural and food sectors. There are very significant agricultural and food security dimensions to the recently experienced problems of short run adjustment. There are several dimensions to this. First, the growing dependence of middle income and low income countries on imported food (not only cereals, but also sugar, vegetable oils, dairy products, etc) has increased the short run problem of food insecurity. Second, there is a growing dependence of domestic agriculture in developing countries on imported inputs: fertilisers, pesticides, fuel for machinery, processing and trucking. These problems are of long standing in export-oriented economies, for example sugar producers. The growing food import dependence is linked to rapid expansion of urban markets and income growth. As a consequence, in the short run, more countries are becoming vulnerable to domestic production instability, fluctuations in the international markets for their food imports as well as exports, and pressures on the supply of intermediate inputs, particularly fossil energy.

The seriousness of these problems as an aspect of short run economic and adjustment difficulties is indicated by current individual country experience, eg Tanzania [Green 1982]. More widely, the United States Department of Agriculture [1982] looking at the food situation for the current year $(1982 / 83)$ has estimated that a large number of low income countries will be faced with serious internal food supply problems and balance of payments pressures that will make it difficult to sustain food consumption at the levels of the late 1970 s unless there is, first, an increase in the aggregate level of food transfers and, second, additional concessional finance to sustain imports.

There is the simultaneous long run policy problem, especially in sub-Saharan Africa, of falls in per capita food production in still largely rural economies [Christensen 1981]. It is a major policy challenge to address these difficulties simultaneously; Michael
Lipton discusses this issue more fully elsewhere in this Bulletin.

\section{The European Community's role The effect of trade policies}

Agricultural growth, stimulated by the CAP, has made the European Community a major force in world agricultural trade. The EC has become a significant source of food on a commercial as well as a concessional basis to many Third World countries. The full extent of these developments, which have been rapid, is not yet fully appreciated. For example, even the United Kingdom which for two centuries was a net importer of cereals, has a net exportable surplus of some $2 \mathrm{mn}$ tonnes during 1982/83. The EC is widely known to provide skimmed milk powder (SMP) as food aid (approximately 150,000 tonnes annually in recent years). Commercial exports of SMP to the Third World have also expanded dramatically. The relative importance of commercial sales can be gauged from the example of Mexico which in recent years has imported a quantity equivalent to approximately half the level of recent total annual allocations of food aid. However, in contrast to the other 'traditional' temperate zone agricultural exporters, the EC has managed the development of exports to a significant extent under short run policies for coping with surpluses.

The influence of EC trade policies in many markets for agricultural products is complex and controversial. The effects of quota agreements for imports have to be balanced against the policy, in a number of markets, of exporting against restitutions (subsidies) with destabilising implications for Third World exports and imports. The most widely recognised example is probably sugar. The EC has agreed quotas for imports with ACP exporters, largely the traditional suppliers to the UK market, at prices that have usually been substantially above world market levels. However, the $\mathrm{EC}$ also undercuts the world market for developing as well as developed country producers by using subsidised exports to manage internal surpluses. Another recent example, indicative of the complex implications of these policies, is provided by the experience of Botswana as a beef exporter. On the one hand, Botswana has a small quota of exports to the EC with severe quality controls. But, on the other hand, it faces competition from the EC in third markets: during 1981/82 EC exports replaced Botswana exports to Angola in contracts that were significantly below those negotiated by the two African countries in the previous year. ${ }^{2}$ In the foreseeable future, expansion of the EC threatens to have negative implications for, at the least, a subgroup of developing countries around the Mediterranean as well as others

${ }^{2}$ Personal communication from Charles Harvey, June 1982. 
with export possibilities for a comparable range of products. As already noted, short run adjustments created by fluctuations in export revenue can be just as much a source of food insecurity as problems created by import prices or domestic production.

In the context of the problems of food insecurity and short run adjustment, the major questions concern the role of the EC in trade and trade negotiations over temperate cereals. EC trade policies during the early 1970 s were a factor in shifting the burden of adjustment to rising prices onto a residual group, including developing countries.

Internal prices for EC-produced cereals and imports (with duty) of grain, both for human consumption and animal feed, are set well above long run world market levels. Imports are therefore insensitive over a wide range to movements in world market prices. These policies stabilise direct human consumption and production of animal products within the Community. This provides European food security. However, the external consequence of such policies, as followed by the EC as well as other important food importing countries including Japan, the USSR and Eastern Europe, is that the burden of adjustment in world markets falls particularly heavily on the United States livestock sector and on developing countries. The most vulnerable are countries whose capacity to import is constrained by their foreign exchange position.

The EC has subsequently played a constructive role in cereal negotiations through its willingness to participate in market stabilisation. However, its interest in maintaining world prices at levels closer to historically higher EC internal prices has obvious negative implications for developing country food importers. Negotiations on a new International Grains Agreement are currently on ice given United States opposition to the management of markets through the use of buffer stocks over which there is some form of international control. In the absence of internationally agreed arrangements for cereal markets the EC participates in the informal discussions amongst cereal exporters. The shift from attempting to find a formal institutional approach to market management to seeking an informal exporter cartel nevertheless makes it less likely that there will be a recurrence of the disorderly markets of the early 1970 s, despite evidence of growing tension between the EC and the United States over export policies in currently softer market conditions [Gilmore and Huddleston 1983].

There is also a complex set of international institutional arrangements for the organisation of food aid in cereals. The Food Aid Convention, formally linked to the International Grains Agreement but in practice separately negotiated, has set a floor level of $7.6 \mathrm{mn}$ tonnes for donor commitments up to 1986. The operation of this Convention is supervised by a Food Aid Committee (FAC) of donors meeting under the auspices of the International Wheat Council [Parotte 1983]. There is also the UN Committee on Food Aid Policies and Programmes (CFA) which sets guidelines for food aid policies and supervises the operations of the World Food Programme and International Emergency Food Reserve (IEFR), involving both donors and recipient countries. There are three other institutions with a role in these matters: the World Food Council (WFC) concerned with policy issues, the FAO Committee on Food Security, and the FAO Committee on Surplus Disposal involving exporting countries and responsible for ensuring that food aid and other concessional arrangements do not disrupt normal commercial trade.

This complex of institutional arrangements covering cereals trade and aid indicates why, in practice, discussions of the role of the EC in relation to world hunger have tended to be concerned only with the development assistance programmes of the Community and constituent member states. There is a problem of multiple objectives. The delinking and compartmentalisation of issues makes it possible to negotiate in a narrow framework, with other objectives treated as effective constraints on the discussion. For example, negotiation of the overall EC cereals food aid commitment in the context of the FAC takes as given the existing internal and trade policies for cereals which are generating sizeable level of surpluses in the medium term. Consequently, and perhaps inevitably within the foreseeable future, discussions of Europe's 'role' in combatting world hunger have come to focus on the Community's development assistance programme, the Lomé group of countries, and linkages between different components of Community assistance at the individual country level. So far, internal Community political considerations have been paramount in relation to the wider trade issues. In addition, Europe is just one party in a complex set of market relationships dominated by a small number of exporting and importing countries. The Community could become a force for more constructive policies on the part of developed countries as a whole, along such lines as suggested by the Brandt Commission. However, because existing trade arrangements imply a particular distribution of gains and losses amongst developed countries, including those who have not been historically party to international agreements on commodities - notably Eastern Europe and the Soviet Union, it would be unrealistic to expect any unilateral action on the part of the Community to 
liberalise trade policies where a significant share of the gains would accrue to other developed countries. ${ }^{3}$

\section{Lomé and Stabex}

Within the more restricted context of EC development assistance policy, there is scope for constructive initiatives, for example over the operation of Stabex, and the operation of Community food aid, including the currently fashionable emphasis on linking different components of development assistance to supporting food strategies at the individual country level.

The recent modification of the IMF Compensatory Financing Facility (CFF) to take account of fluctuations in the bill for cereal imports with an accompanying small increase in the scale of possible drawings by members, provides a possible model for modification of the Stabex compensation scheme for fluctuations in export earnings [Green and Kirkpatrick 1981, 1982]. The linking of some genuine element of additionality, however modest, to the modification of the Stabex facility to accomodate food imports would be a constructive step. From the viewpoint of eligible countries, what is critical is the expected cost of imports in relation to export revenues, not just the level of export revenues. As the IMF CFF is typically only sufficient to take account of a proportion of the fluctuations in expected export revenues or import costs, the move would be complementary, even if restricted in application to a limited number of countries. However, such a development may raise questions of associated conditionality, since the level and commodity composition of food imports is determined by most of the Lomé country governments in relations to the availability of concessional supplies and other competing demands for foreign exchange.

\section{European Community Food Aid}

The EC is now second only to the United States as a food aid donor in terms of development assistance expenditure. It accounted for 33 per cent of transfers from OECD countries in 1981 (Table 1), and 22 per cent of commitments under the Food Aid Convention (Table 2). Just over two-thirds of this food aid is administered by the Commission as 'Community Action' (henceforth called the 'Community programme') and the remainder as 'national actions of nine member states'. The programming and operation of the Commission administered programme have recently come under close scrutiny and have been subject to considerable criticism in the European Parliament and in a special report of the EC Court of Auditors [1980]. There has also been recent IDS

'For a recent exploration of these questions, see Koestler [1982], who examines options for the EC grain economy: continuation of high protection policies of the past, complete liberalisation, and modifications of policy to make internal markets more sensitive to world market conditions. involvement in reviewing EC food aid, first in a study of the costs and value of the resource transfer and subsequently in an evaluation of impact on recipient countries.

Viewed as a resource transfer, the scale of food aid is modest in relation to both the cereal imports of developing countries and the total development assist ance and financial flows between developed and developing countries. In 1981 it totalled some US $\$ 3 \mathrm{mn}$, and over $8 \mathrm{mn}$ tonnes of cereals. However, food aid has particular significance in representing a source of quick disbursing balance of payments and budgetary support for developing countries The nature of the short run impact on the recipient's domestic economy, including agriculture, depends on the extent to which the food transfers substitute for commercial imports or represent additional imports. A recent literature review [Clay and Singer 1982] concluded that currently most cereals food aid substitutes for commercial imports, directly providing balance of payments support, and suggesting that it has a significant positive short run role.

Serious problems arise, however, at the overall level of programming food aid, as has been indicated clearly by recent shortfalls in actual shipments of cereals as compared with commitments made by the Community under the Food Aid Convention and original Community allocations (Table 2). In 1981 the decision of the Council of Ministers on Commission proposals, and consequently implementation of the programme, were delayed by over three months in the run up to the French presidential election. In 1982 Commission proposals became a political football between the Parliament and the Council. Consequently proposals made in February 1982 for better cereals food aid, in addition to commitments under the Food Aid Convention, were not approved until towards the end of the year (and then only partially). Food aid is not a near frictionless transfer. Commodities have to be procured, appropriately packaged, inspected, shipping organised arrangements which involve not only the Commission and recipient country governments, but also national intervention boards, traders, shippers, port authorities etc. Such problems have made the Community food aid programme less than effective as a mechanism for meeting part of the food import requirements of many developing countries.

Such problems of programming are particularly unfortunate in the context of the increasing problems of economic adjustment among low income countries. A policy intervention is procyclical when it amplifies rather than dampens cyclical fluctuations in prices and quantities produced or consumed. Food security interventions are normally intended to be counter cyclical in relation to food consumption. At the very 
Table 1

Food aid flows by type of official transaction of OECD countries in 1981

(US\$ $\mathrm{mn}$ )

\begin{tabular}{|c|c|c|c|c|c|}
\hline \multirow[b]{2}{*}{ donor country } & \multirow[b]{2}{*}{ grants } & \multicolumn{3}{|c|}{ food aid (net disbursements) } & \multirow[b]{2}{*}{$\begin{array}{l}\text { donor total as } \\
\text { percentage of } \\
\text { total food aid }\end{array}$} \\
\hline & & loans & $\begin{array}{c}\text { contributions to } \\
\text { international } \\
\text { institutions } \\
(\$ m n)\end{array}$ & total & \\
\hline Australia & 83.7 & 0.0 & 19.0 & 102.7 & $3.5 \%$ \\
\hline Canada & 70.4 & 6.2 & 86.1 & 162.8 & $5.5 \%$ \\
\hline EC 'National actions' & $(209.7)$ & $(0.0)$ & $(73.5)^{1}$ & $(283.2)^{1}$ & $(9.7 \%)^{1}$ \\
\hline 'Community actions' & $(459.6)^{1}$ & $(0.0)$ & $(212.2)^{1}$ & $(671.8)^{1}$ & $(22.9 \%)^{1}$ \\
\hline Total & 669.3 & 0.0 & $285.7^{1}$ & 955.0 & $32.5 \%$ \\
\hline Japan & 24.1 & 298.5 & 23.6 & $346.2^{2}$ & $11.8 \%$ \\
\hline United States & 430.0 & 693.0 & 139.0 & 1262.0 & $43.0 \%$ \\
\hline Other ${ }^{3}$ & 30.8 & 0.0 & 75.2 & 105.9 & 3.6 \\
\hline Total & $1308.3^{1}$ & 997.8 & $628.4^{1}$ & $2934.5^{2}$ & 100.0 \\
\hline
\end{tabular}

Source: Development Cooperation 1982 Review, OECD, Development Assistance Committee, Paris.

Note: ${ }^{1}$ Own estimate. The multilateral contributions of individual member states as reported by the DAC include national estimates of 'contributions' to the financing of EC action. Due to rounding errors there are small differences between some row and column totals.

${ }^{2}$ Own estimate - DAC reports $\$ 26.4 \mathrm{mn}$ of gross disbursements by Japan, in addition to the sub-totals for grant, loans and multilateral contributions.

${ }^{3}$ Other: Austria, Finland, Norway, Sweden, Switzerland.

least, they should be neutral in impact. But food aid has indeed proved to be procyclical, least available when most required, in spite of the floor provided by the 1980 Food Aid Convention. This is because the USA, the major donor, budgets food aid in financial rather than volume terms so that tight market conditions result in a reduced level of food aid [Clay and Singer 1982]. Consequently, cereals food aid shipments fell by 6 per cent from a post world food crisis peak in $1978 / 79$ of $9.5 \mathrm{mn}$ tonnes to only $8.9 \mathrm{mn}$ tonnes in $1980 / 81$, partly because of US budgeting procedures and partly because of the programming problems encountered particularly by the Community. Since then commitments and actual shipments have been increasing once again in the softer market conditions recently prevailing.

Approximately two-thirds of the Community food aid programme is accounted for by dairy products. Dairy. food aid mostly represents additional food imports which do not substitute for commercial imports of the same products. Butter oil, for example, is a costly substitute for other vegetable-based cooking media in countries as different as Bangladesh, Lesotho and Sri Lanka which have all been recipients under the Community programme. The problems of effective and safe use of SMP have been reflected in the increasing importance assigned to high cost supply to large numbers of small nutrition projects under the auspices of NGOs and international agencies in many countries. The nutritional effectiveness of direct distribution programmes remains an area of controversy [Jackson 1982]. Butter oil and SMP are also supplied for reconstitution as milk products in dairy development programmes. The reconstitution of dairy products for cheese manufacture in Egypt may, of course, be a useful form of economic transfer, but it does not make direct impact on the problems of hunger and food security. Evidence is wanting to prove that these products are at all cost-effective as a form of resource transfer.

There would appear to be possibilities for increasing the effectiveness of Community food aid, even within current budgetary limits, through the substitution of more cereals for dairy products. Alternatively, a reduction in food aid and an increase in some other quick disbursing form of assistance, such as extending Stabex - as discussed above, might be a more effective channel for assistance. It is encouraging to find opportunities at the donor end for increasing the cost effectiveness of development assistance. If the dairy food programme is, to a considerable extent, the consequence of the early build-up of surpluses, then 
the success of aggressive export policies may reduce the internal Community problems of adjustments in the commodity and commodity/financial composition of the basket of assistance.

\section{The relationship between food aid and food strategies}

Where there are severe problems is at the individual country level, and in this respect food aid provides an entry point for viewing the wider problem. At this level there are difficult programming issues which may be considered in the context of linkage between three elements: EC and other bilateral commodity assistance which has normally been programmed on an individual donor basis, with one or two recent exceptions such as Mali and possibly Bangladesh; other EC development assistance; and the commodity context in a recipient economy.

This is a difficult policy area recognised explicitly by the EC Commision [1982] in its espousal of the concept of 'food strategies'. These proposals imply that Community aid through different channels of assistance, including food aid, would be organised on a multi-year basis to support an agriculture sector development 'strategy' directed to increasing domestic food production. This idea runs up against a difficulty that cannot be avoided with respect to food aid concerning the linkages between concessional and

Table 2

Cereals food aid: donor commitments under 1980 Food Aid Convention, allocations and actual shipments in 1980/81

\begin{tabular}{|c|c|c|c|c|c|c|}
\hline \multirow[t]{2}{*}{ donor countries } & $\begin{array}{c}\text { commitments } \\
\text { under } \\
1980 \mathrm{FAC} \\
\end{array}$ & $\begin{array}{c}\text { allocations } \\
1980 / 81\end{array}$ & $\begin{array}{c}\text { actual } \\
\text { shipments } \\
1980 / 81\end{array}$ & $\begin{array}{c}\text { allocations } \\
\text { for } 1980 / 81 \\
\text { as } \% \text { of } F A C \\
\text { commitment }\end{array}$ & $\begin{array}{c}\text { shipments } \\
\text { in } 1980 / 81 \\
\text { as } \% \text { of FAC } \\
\text { commitment }\end{array}$ & $\begin{array}{c}\text { shipments as } \\
\% \text { of } \\
\text { allocations } \\
\text { for } 1980 / 81\end{array}$ \\
\hline & \multicolumn{3}{|c|}{ (000 tonnes) } & \multicolumn{3}{|c|}{$(\%)$} \\
\hline Argentina & 35 & 48 & 67 & 137 & 191 & 140 \\
\hline Australia & 400 & 400 & 370 & 100 & 93 & 93 \\
\hline Austria & 20 & 20 & 32 & 100 & 160 & 160 \\
\hline Canada & 600 & 600 & 600 & 100 & 100 & 100 \\
\hline China & - & (25) & 2 & - & - & (8) \\
\hline $\mathrm{EEC}$ & $1,650^{1}$ & $1,650^{1}$ & $1,263^{1}$ & 100 & 77 & 77 \\
\hline Finland & 20 & 20 & 29 & 100 & 145 & 145 \\
\hline India & - & 50 & 51 & - & - & - \\
\hline Japan & 300 & 567 & 893 & 189 & 298 & 157 \\
\hline Norway & 30 & 40 & 40 & 133 & 133 & 100 \\
\hline Saudi Arabia & - & (10) & 31 & - & - & - \\
\hline Spain & 20 & 20 & 14 & 100 & 70 & 70 \\
\hline Sweden & 40 & 90 & 94 & 225 & 235 & 110 \\
\hline Switzerland & 27 & 27 & 16 & 100 & 59 & 59 \\
\hline Turkey & - & 10 & 15 & - & - & 一 \\
\hline United States & 4,470 & $5,262^{2}$ & 5,212 & 118 & 117 & 99 \\
\hline WFP purchases & - & $(50)$ & 13 & - & - & - \\
\hline Other & 一 & $(165)$ & 166 & - & - & 一 \\
\hline Total & 7,612 & 9,054 & 8,908 & 119 & 111 & 93 \\
\hline
\end{tabular}

Source: Food Aid Convention, 1980; FAO Food Aid Bulletin, no 4, 1982.

Note: Other cereals food aid, under $1971 \mathrm{FAC}$, was also shipped in 1980/81.

'Includes shipments in wheat equivalent by member nations, ('National actions") as well as 'Community actions' - in 1980/81, 928,000 tonnes were designated for 'Community actions' and 722,000 tonnes for 'National actions'.

${ }^{2}$ Includes the grain equivalent of the budgetary allocation for fiscal year 1981 (Oct 1980-Sept 1981), as well as the estimated grain equivalent of the supplemental allocations of US\$ $142 \mathrm{mn}$ for fiscal year 1980, approved by the Congress in July 1980 . 
commercial trade policy, and between the EC and the programmes of other donors. The link between commercial and concessional trade is institutionalised in the EC Commission by the involvement of DG 6 (Agriculture) in the negotiation of the Usual Marketing Requirement (UMR). This occurs under the FAO rules of surplus disposal, and indicates the level of commercial imports to be made by a food aid recipient. The tension between aid and agricultural trade policies makes it more difficult to provide additional food aid to a country with a constant or falling level of imports.

The USA, in contrast to the EEC, has always sought a close integration of aid and agricultural policy, and as a result the programming of food aid has provided many examples of the difficult tension between developmental and trade promotion objectives [Clay and Singer 1982].

In reviewing the other linkages implied by a food strategy, it is important to take note of the United States' unsatisfactory experiences in attempting to link food aid to its other bilateral assistance either by earmarking the counterpart funds generated by food aid sales, or by using bilateral food aid for economic policy leverage. In the late 1970 s the USA introduced the new PL 480 Title III for programme food aid involving multi-year priority and additional concessionality. The conditions attached were that the counterpart funds generated by the local sale of food aid commodities should be used to support additional agricultural developmental activity and that the government should also make improvements in general economic policy, particularly in relation to the agricultural sector. The United States and many recipient countries have found the requirements for such agreements, including additional pressures on managerial and monitoring capacity on both sides, too great. In consequence only a few countries have entered into such agreements. Another interesting development has occurred in Bangladesh. There was some unhappy early experience on the American side with the attempt to apply leverage in relation to the conditions ('self help measures') of a Title III agreement on agricultural pricing, as well as unsatisfactory use of counterpart funds. The United States has now agreed that counterpart funds be used to meet the local costs of high priority World Bank funded rural sector projects.

The United States experience, illustrated here with only a few examples, underscores the limitations on individual donor action. The reality is that most food aid recipients receive support from a range of donors, as with other forms of assistance. Such resources are part of the food import and food balance equations and also provide budgetary support. The most important 'linkage' issue for food aid is therefore the scale, commodity composition and timing of the different donor supplies in relation to the food system operations of the recipient government. In the longer run, the context of such transfers in relation to the food, and more broadly the agricultural sector strategy, is very important. There is, however, no particular 'macro' food policy logic, from the recipient country viewpoint, in emphasising linkages between food aid and other components of assistance provided by an individual donor, unless perhaps there is genuine additionality in the level of aid. What makes more sense, given the complexity of food aid relationships, would be for a particular donor to play a 'lead agency role' in attempting to rationalise food aid as part of a consistent multi-donor package. In practice, because bilateral policy is more important for food aid than for other development assistance, this could be a role which could be played conceivably, depending on the context, by the EC through its Community programme, a member state, the USA, or another donor.

The concept of a food strategy is challenging in that it focuses attention on the problem of programming food and other support with short run impact, which is all too often provided in an emergency context, whilst taking account of the longer run. The problems are country-specific, which implies that attempts to move in a more constructive direction would have their own timetable. There could arise a tension, therefore, between concern to increase the effectiveness of assistance at the country level and the overall macro objective of providing the largest possible scale of adjustment assistance. This problem is again illustrated in a United States context by the way in which food aid has been switched rapidly towards Africa, partly in response to the legislative requirements to target more food aid on low income countries. The US experience is also a warning that the EC cannot go it alone successfully, but could play a constructive role in facilitating positive donor group action. Third, constructive food strategies are likely to require additional complementary programme lending in the short run, eg to finance fertiliser imports, as well as capital assistance. Again, a balanced complementary package of resources is more likely to be provided by consortium action.

The emphasis in this article has been on areas in which there are practical possibilities in the immediate future for donor-end improvements in development assistance. In the context of the current emphasis on 'management problems' in developing countries, it is salutary to recognise that these possibilities for improvement are the consequence of existing inadequacies at the donor-end. However, many of these problems result from the evolution of 
development assistance and trade policies in the context of the CAP. Longer term, more coherent policies are difficult to formulate in what is treated, at one level, as a temporary situation, pending the reform of the CAP. But in practice in the absence of any evidence that there will be significant restructuring of the CAP, particularly given the problems presented by new entrants, development assistance policies are in danger of being condemned to formulation in a context that might be described as one of permanent impermanence. That is why the current emphasis on 'food strategies' is attractive because it requires that food aid be programmed in a longer term context, even if it does not offer any novel and simple solution to the tough, if not intractable, problems of food insecurity and agricultural development.

\section{References}

Christensen, C. and others, 1981, 'Food problems and prospects in sub-Saharan Africa', Foreign Agricultural Research Report no 166, US Department of Agriculture, Washington DC

Clay, E. J., 1982, 'Food aid and food security in sub-Saharan Africa' in Agricultural Development Council, The Developmental Effectiveness of Food Aid in Africa, New York

-and others, 1981, 'Food policy issues in low income countries', Staff Working Paper no 473, World Bank, Washington DC

-and J. Pryer, 1982, 'Food aid: issues and policies', Discussion Paper 183, IDS, Sussex, November

-and H. W. Singer, 1982, 'Food aid and development: the impact and effectiveness of bilateral PL 480 title I type assistance, AID Program Evaluation Discussion Paper no 15 , Washington DC, December

European Communities Commission, 1981, Towards a Plan of Action to Combat World Hunger (Commission Communication to the Council) COM(81) 560 final, Brussels, 5 October
European Communities Commission, Directorate-General for Information, 1982, Food Strategies: a New Form of Cooperation between Europe and Countries of the Third World, DE40 (X374/82), Brussels, December

European Communities Council, 1981, Stocktaking of Community Aid in the Agricultural and Food Sectors, 10257/81, Brussels, 28 October

European Communities, Court of Auditors, 1980, Special Report on Community Food Aid, Brussels, 30 October

European Parliament, 1980, Report on the European Community's Contribution to the Campaign Against Hunger in the World, Doc P-341/80, Luxembourg, September

-1982, Official Journal (OJ) Annex: Debates of the European Parliament 1982-1983, no 1-286, pp 107-139, 14-18 June

Gilmore, R. and B. Huddleston, 1983, 'The food security challenge', Food Policy, vol 8 no 1, February

Green, C. and C. Kirkpatrick, 1981, 'Insecurity, food financing and the IMF', Food Policy, vol 16 no 3

-1982, 'The IMF's food financing facility', Journal of World Trade Law, vol 16 no 3

Green, R. H., 1982, 'Agricultural crises in sub-Saharan Africa: capitalism and transitions to socialism', Bulletin, vol 13 no 4 , IDS, Sussex

Jackson, A., with D. Eade, 1982, Against the Grain, Oxfam, Oxford

Koestler, U., 1982, 'Policy options for the grain economy of the European Community: implications for developing countries', Research Report no 35, International Food Policy Research Institute, Washington DC

Parotte, J. H., 1983, 'The Food Aid Convention: its history and scope', Bulletin, vol 14 no 2, IDS, Sussex

United States Department of Agriculture, 1982, World Food Aid Needs and Availabilities 1982, Economic Research Service, USDA, Washington DC, April 